\title{
RISK FACTORS ASSOCIATED WITH THE OCCURRENCE OF EARLY COMPLICATIONS OF ACUTE MYOCARDIAL INFARCTION AFTER CARDIO-INTERVENTION TREATMENT
}

DOI: 10.36740/WLek202006132

\author{
Iryna A. Holovanova, Grygori A. Oksak, Iryna M. Tkachenko, Maxim V. Khorosh, Mariia M. Tovstiak, Yevhen Yu. Strashko \\ UKRAINIAN MEDICAL STOMATOLOGICAL ACADEMY, POLTAVA, UKRAINE
}

\begin{abstract}
The aim of our study was to identify the main risk factors for the occurrence of early complications of acute myocardial infarction after cardio-interventional treatment and to evaluate prognostic risk indicators.

Materials and methods: Risk factors of myocardial infarction were determined by copying the case history data and calculating on their basis of the odds ratio and $\pm 95 \%$ confidence interval. After it, we made a prediction of the risk of early complications of AMI with cardiovascular intervention by using a Cox regression that took into account the patient's transportation time by ambulance.

Results: Thus, the factors that increase the chances of their occurrence were: summer time of year; recurrent myocardial infarction of another specified localization (I122.8); the relevance of the established STEMI diagnosis; diabetes mellitus; renal pathology; smoking; high rate of BMI.

Factors that reduce the chances of their occurrence: men gender - in $35 \%$; the age over of 70 - by $50 \%$; the timely arrival of an emergency medical team - by $55 \%$. The factors that increase the chances of their occurrence were: age over 70 years; subsequent myocardial infarction of unspecified site; diabetes mellitus.

Using of a Cox regression analysis, it was proved that the cumulative risk of early complications of AMI with cardio-intervention treatment increased from the 10th minute of ambulance arrival at place, when ECG diagnosis (STEMI), presence of diabetes mellitus, smoking and high BMI.

Conclusions: As a result of the conducted research, the risk factors for early complications of AIM with cardio-interventional treatment were identified.
\end{abstract}

KEY WORDS: acute myocardial infarction, cardio-interventional treatment, odds ratio, Cox regression

Wiad Lek. 2020;73(6):1245-1251

\section{INTRODUCTION}

The issue of coronary heart disease is one of the most important medical problems in the world (heart attack aka myocardial infarction, coronary heart disease, angina pectoris) $[1,2,3,4]$. In acute myocardial infarction (AMI), unlike other cardiovascular diseases, timely pre-hospital and emergency treatment ensures successful recovery of the patient and a better prognosis. Ignoring of these principles can leads to increasing of mortality rates, even among young people $[5,6]$.

After conducting of reperfusion therapy, it is important to identify patients at high risk for further cardiac events, such as re-infarction or death, and make intervention to prevent such complications [7]. As the risk of adverse events decreases over time, an early assessment of the risks is necessary. The assessment of the size of the infarct area and function of the left ventricle at rest, as a rule, by the method of echocardiography, should be done before discharge of the patient from the hospital $[8,9]$. The timing of follow-up will depend on whether the treatment was performed and whether the angiography and percutaneous coronary intervention (PCI) were successful. Assessment of ischemia risk prior to hospital discharge has become less important, due to the increased use of primary PCI, which makes it possible to assume that infarct-dependent coronary lesions have been treated and stabilized, and the presence or absence of significant lesions in other arteries has been evaluated.

Several parameter-based risk assessment scales have been developed and put into practice that allow one to easily identify the risk in the acute phase before reperfusion [10, 11, 12]. High-risk clinical indicators in the acute phase include older age, tachycardia and tachyarrhythmia, hypotension, more than 1 score in Killip-Kimball scale, anterior infarction, history of heart attack, elevated serum creatinine and heart failure. Malignant arrhythmia, persistent chest pain, and early angina with minimal physical activity are considered to be poor results of treatment $[13,14,15]$.

The recommendations of the Association of Cardiologists of Ukraine regarding the management of patients with acute coronary syndrome with ST segment elevation are of great help in the practice of dealing with such patients [16].

\section{THE AIM}

The aim of our study was to identify the main risk factors for the occurrence of early complications of acute myocar- 
Table 1. Prognostic variables associated with risk factors for early complications of AMI after cardio-intervention treatment

\begin{tabular}{ccc}
\hline Prognostic variables & Prognostic variables & Prognostic variables \\
\hline Age & Body mass index & ECG diagnosis \\
\hline Gender & Smoking & $\begin{array}{c}\text { The onset of symptoms before the } \\
\text { emergency call (more than 120 minutes) }\end{array}$ \\
\hline Place of residence & Increase in blood pressure & $\begin{array}{r}\text { Emergency arrival time (more than } 10 \text { min } \\
\text { in Poltava) }\end{array}$ \\
\hline Complications & Pain in the heart & $\begin{array}{c}\text { The start time of the PCI from the moment } \\
\text { of the ECG }\end{array}$ \\
\hline Death & The concomitant renal pathology & Diabetes mellitus
\end{tabular}

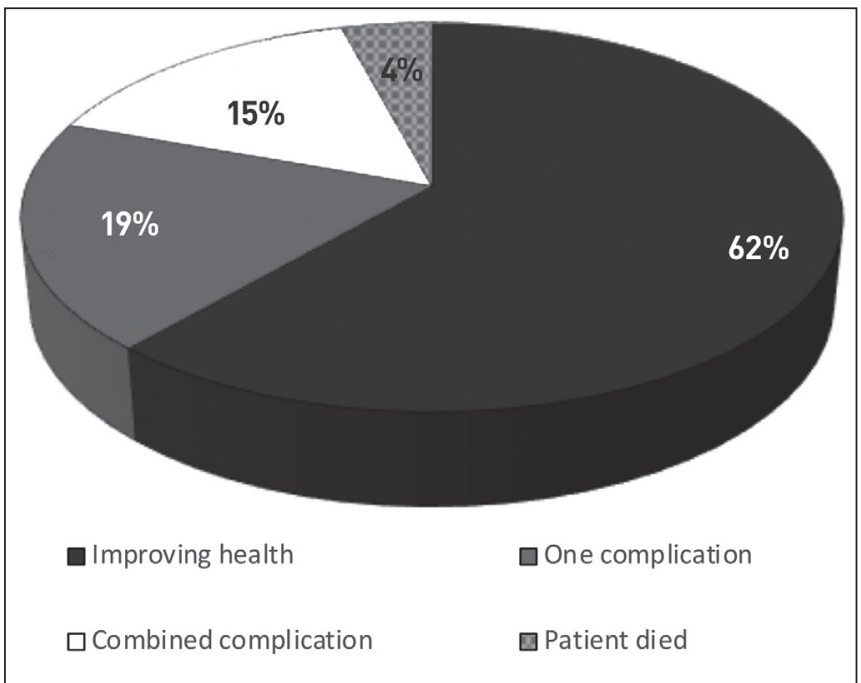

Fig. 1. Distribution of patients according to the results of cardiointerventional treatment.

dial infarction after cardio-interventional treatment and to evaluate prognostic risk indicators.

\section{MATERIALS AND METHODS}

Risk factors of myocardial infarction were determined by copying the case history data and calculating on their basis of the odds ratio. To achieve this goal, we calculated the next indexes: odds ratios (OR) and $\pm 95 \%$ confidence interval (95\% CI).

The coefficient of OR was calculated by the formula:

In this formula: $\mathrm{a}$ - the number of patients with complications of AMI in the presence of a risk factor; $b$ - the number of patients without the complication of AMI in the presence of a risk factor; $\mathrm{c}$ - number of patients with complications of AMI in the absence of a risk factor; $d$ - number of patients without complication of AMI in the absence of risk factor.

The following complications of AIM that occurred during cardio-intervention treatment were considered:

- aortic aneurysm;

- arrhythmia;

- reduction of blood fraction;

- cardiogenic shock;

- pulmonary edema.
To identify significant risk factors, there is 17 prognostic variables were considered, and all these variables are related to the identification of risk factors for early complications of AMI after cardio-intervention treatment (Table I).

After determining of the odds ratio for prognostic variables, we made a prediction of the risk of early complications of AMI with cardiovascular intervention. This risk was calculated using a Cox regression that took into account the patient's transportation time by ambulance. The object of observation is a patient with AMI who has been delivered to a tertiary level of healthcare system. The determination of the predicted risk of early complications of AMI with cardiovascular intervention, lasting up to $10-20$ minutes, was estimated by Cox regression as an influence on this risk of independent variables (predictors). For this study, those predictors that were found to be significant in the odds ratio study were selected. Risk is defined as a function of time. The risk of an event occurring for an object is given as a formula:

$$
\text { hi }(\mathrm{t})=\mathrm{h} 0(\mathrm{t}) \exp \left(\beta_{1} \mathrm{Xi}_{1}+\beta_{2} \mathrm{Xi}_{2}+\ldots+\beta_{\mathrm{p}} \mathrm{Xi}\right)
$$

In this formula: hi $(\mathrm{t})$ - basic risk that is the same for all entities; $\beta_{1}, \ldots, \beta_{p}$-coefficients; $X_{1}, \ldots, X_{p}$ - independent variables, predictors.

Base risk - ho ( $t$ ) - is the risk of an event occurring for an object in the reference group (with all independent variables $\mathrm{X}_{1}, \ldots, \mathrm{X}_{\mathrm{p}}$ being equal zero). Statistical analysis of the results of the study was performed using statistical analysis methods implemented in the SPSS 6.1 software package.

The result of treatment by the method of cardio-intervention was determined by the presence of complication or improvement of the patient's condition. The following factors that could affect the completion of treatment were considered:

1. Natural and climatic genesis:

- Seasonality

2. Medical and demographic genesis:

- Place of residence

- Gender

3. Organizational genesis:

- Carrying out a troponin test

- The time of arrival of emergency medical care and conducting of ECG

- The time of arrival of the patient in the reception department from the conducting of ECG

- Thrombolytic therapy at the pre-hospital stage

- The start time of the PCI from the conducting of ECG 
Table 2. Distribution of patients by risk factors according to the complication after cardiac intervention

\begin{tabular}{|c|c|c|c|c|}
\hline Risk factor & $\begin{array}{c}\text { Patients with } \\
\text { complications } \\
\text { abs. }(\%) \\
n=85(36,8)\end{array}$ & $\begin{array}{c}\text { Patients with } \\
\text { improvement } \\
\text { abs. }(\%) \\
n=146(63,2) \\
\end{array}$ & $\begin{array}{l}\text { Odds ratio } \\
\text { (95\% CI) }\end{array}$ & $\mathbf{p}$ \\
\hline Winter & $\begin{array}{c}0 \\
(0 \%) \\
\end{array}$ & $\begin{array}{c}88 \\
(29,7 \%) \\
\end{array}$ & - & - \\
\hline Spring & $\begin{array}{c}20 \\
(11,8 \%) \\
\end{array}$ & $\begin{array}{c}58 \\
(19,1 \%) \\
\end{array}$ & $\begin{array}{c}1,780 \\
(0,818-3,874)\end{array}$ & 0,197 \\
\hline Summer & $\begin{array}{c}100 \\
(58,8 \%)\end{array}$ & $\begin{array}{c}44 \\
(14,9 \%)\end{array}$ & $\begin{array}{c}8,052 \\
(4,305-0,232)\end{array}$ & 0,001 \\
\hline Autumn & $\begin{array}{c}50 \\
(29,4 \%) \\
\end{array}$ & $\begin{array}{c}106 \\
(36,3 \%)\end{array}$ & $\begin{array}{c}1,368 \\
(0,769-5,0623)\end{array}$ & 0,315 \\
\hline Man & $\begin{array}{c}112 \\
(65,9 \%) \\
\end{array}$ & $\begin{array}{c}222 \\
(75,0 \%) \\
\end{array}$ & $\begin{array}{c}0,655 \\
(0,426-0,972) \\
\end{array}$ & 0,024 \\
\hline Age $19-49$ years & $\begin{array}{c}54 \\
(26,7) \\
\end{array}$ & $\begin{array}{c}63 \\
(23,9) \\
\end{array}$ & $\begin{array}{c}0,918 \\
(0,452-1,865) \\
\end{array}$ & 0,856 \\
\hline Age $50-69$ years & $\begin{array}{c}87 \\
(43,1) \\
\end{array}$ & $\begin{array}{c}139 \\
(52,8) \\
\end{array}$ & $\begin{array}{c}1,676 \\
(0,964-2,913) \\
\end{array}$ & 0,088 \\
\hline Age over 70 years & $\begin{array}{c}61 \\
(30,2) \\
\end{array}$ & $\begin{array}{c}61 \\
(23,2) \\
\end{array}$ & $\begin{array}{c}0,508 \\
(0,261-0,987)\end{array}$ & 0,050 \\
\hline Place of residence: Poltava & $\begin{array}{c}100 \\
(49,4 \%) \\
\end{array}$ & $\begin{array}{c}132 \\
(50,7 \%) \\
\end{array}$ & \multirow{2}{*}{$\begin{array}{c}0,950 \\
(0,557-1,622)\end{array}$} & \multirow{2}{*}{0,892} \\
\hline Place of residence: another region & $\begin{array}{c}101 \\
(50,6 \%) \\
\end{array}$ & $\begin{array}{c}130 \\
(49,3 \%) \\
\end{array}$ & & \\
\hline $\begin{array}{l}\text { DS: Subsequent myocardial infarction } \\
\text { of unspecified site }\end{array}$ & $\begin{array}{c}37 \\
(8,6)\end{array}$ & $\begin{array}{c}35 \\
(13,1 \%) \\
\end{array}$ & $\begin{array}{c}2,15 \\
(1,224-5,183) \\
\end{array}$ & 0,014 \\
\hline $\begin{array}{l}\text { Time from the onset of symptoms to } \\
\text { a emergency call (more than } 120 \text { minutes) }\end{array}$ & $\begin{array}{c}36 \\
(7,8) \\
\end{array}$ & $\begin{array}{c}66 \\
(14,3) \\
\end{array}$ & $\begin{array}{c}1,107 \\
(0,578-2,119)\end{array}$ & 0,870 \\
\hline $\begin{array}{c}\text { Emergency arrival time } \\
\text { (up to } 10 \text { minutes in Poltava, up to } 20 \text { minutes in regions) }\end{array}$ & $\begin{array}{c}123 \\
(26,4)\end{array}$ & $\begin{array}{c}153 \\
(32,9)\end{array}$ & $\begin{array}{c}0,453 \\
(0,255-0,806) \\
\end{array}$ & 0,008 \\
\hline $\begin{array}{l}\text { Start time of } \mathrm{PCl} \text { after ECG withdrawal } \\
\text { (more than } 120 \text { minutes) }\end{array}$ & $\begin{array}{c}68 \\
(14,7)\end{array}$ & $\begin{array}{c}78 \\
(16,7)\end{array}$ & $\begin{array}{c}1,721 \\
(1,000-2,959)\end{array}$ & 0,056 \\
\hline DS: STEMI & $\begin{array}{c}8 \\
(1,7 \%)\end{array}$ & $\begin{array}{c}30 \\
(6,4 \%)\end{array}$ & \multirow{2}{*}{$\begin{array}{c}2,284 \\
(1,022-5,103)\end{array}$} & \multirow{2}{*}{0,027} \\
\hline DS: NSTEMI & $\begin{array}{c}162 \\
(34,8) \\
\end{array}$ & $\begin{array}{c}266 \\
(57,1) \\
\end{array}$ & & \\
\hline Diabetes mellitus & $\begin{array}{c}149 \\
(32,0) \\
\end{array}$ & $\begin{array}{c}23 \\
(4,9) \\
\end{array}$ & $\begin{array}{c}84,2 \\
(45,1-157,2) \\
\end{array}$ & 0,001 \\
\hline Renal pathology & $\begin{array}{c}74 \\
(15,9) \\
\end{array}$ & $\begin{array}{c}40 \\
(8,6) \\
\end{array}$ & $\begin{array}{c}4,93 \\
(3,144-7,741) \\
\end{array}$ & 0,001 \\
\hline Smoking & $84(18,0)$ & $\begin{array}{c}14 \\
(3,0) \\
\end{array}$ & $\begin{array}{c}19,674 \\
(10,6-36,4) \\
\end{array}$ & 0,001 \\
\hline High BMI & $\begin{array}{c}116 \\
(24,9) \\
\end{array}$ & $\begin{array}{c}22 \\
(4,7) \\
\end{array}$ & $\begin{array}{c}26,754 \\
(15,572-45,96)\end{array}$ & 0,001 \\
\hline Stenting & $\begin{array}{c}78 \\
(91,8 \%) \\
\end{array}$ & $\begin{array}{c}130 \\
(89,0 \%) \\
\end{array}$ & $\begin{array}{c}1,371 \\
(0,540-3,481) \\
\end{array}$ & 0,650 \\
\hline Conservative treatment & $\begin{array}{c}7 \\
(8,2 \%)\end{array}$ & $\begin{array}{c}16 \\
(11,0 \%)\end{array}$ & $\begin{array}{c}1,371 \\
(0,540-3,481)\end{array}$ & 0,650 \\
\hline
\end{tabular}

- The type of PCI

4. Medical genesis:

- ECG diagnosis (STEMI/NSTEMI)

- Diabetes mellitus

- The concomitant renal pathology
- Smoking

- Increasing of BMI

\section{RESULTS}

In determining the consequences of cardio-intervention 
Table 3. Distribution of patients who died after cardiac intervention (by risk factors, respectively)

\begin{tabular}{|c|c|c|c|c|}
\hline Risk factor & $\begin{array}{c}\text { Patients with } \\
\text { complications } \\
\text { abs. }(\%) \\
n=20(6,3)\end{array}$ & $\begin{array}{l}\text { Patients with } \\
\text { improvement } \\
\text { abs. }(\%) \\
\mathrm{n}=296(65,8)\end{array}$ & $\begin{array}{l}\text { Odds ratio } \\
\text { (95\% CI) }\end{array}$ & $\mathbf{p}$ \\
\hline Winter & 0 & $88(29,7)$ & $\begin{array}{c}1,1 \\
(1,053-1,141)\end{array}$ & 0,002 \\
\hline Spring & $6(30,0)$ & $58(19,6)$ & $\begin{array}{c}1,759 \\
(0,648-4,773)\end{array}$ & 0,258 \\
\hline Summer & $6(30,0)$ & $44(14,9)$ & $\begin{array}{c}2,455 \\
(0,895-6,729)\end{array}$ & 0,105 \\
\hline Autumn & $8(40,0)$ & $106(353,8)$ & $\begin{array}{c}1,195 \\
(0,474-3,015) \\
\end{array}$ & 0,811 \\
\hline Man & $14(70)$ & $222(75,0)$ & \multirow{2}{*}{$\begin{array}{c}1,759 \\
(0,6484-4,773)\end{array}$} & \multirow{2}{*}{0,253} \\
\hline Woman & $6(30,0)$ & $74(25,0)$ & & \\
\hline Age over 50 years & $20(100)$ & $248(83,8)$ & $\begin{array}{c}0,925 \\
(0,894-0,957) \\
\end{array}$ & 0,033 \\
\hline Age over 70 years & $12(21,4)$ & $44(14,9)$ & $\begin{array}{c}8,591 \\
(3,322-4,218)\end{array}$ & 0,000 \\
\hline Place of residence: another region & $6(30,0)$ & $134(45,3)$ & \multirow{2}{*}{$\begin{array}{c}0,518 \\
(0,194-1,385)\end{array}$} & \multirow{2}{*}{0,136} \\
\hline Place of residence: Poltava & $14(30,0)$ & $162(54,7)$ & & \\
\hline $\begin{array}{l}\text { DS: Subsequent myocardial } \\
\text { infarction of unspecified site }\end{array}$ & $16(80,0)$ & $64(21,6)$ & $\begin{array}{c}14,500 \\
(4,684-14,890)\end{array}$ & 0,001 \\
\hline $\begin{array}{c}\text { Time from the onset of symptoms } \\
\text { to a emergency call } \\
\text { (more than } 120 \text { minutes) }\end{array}$ & $8(40,0)$ & $64(21,6)$ & $\begin{array}{c}2,417 \\
(0,947-6,165)\end{array}$ & 0,058 \\
\hline $\begin{array}{l}\text { Emergency arrival time } \\
\text { (up to } 10 \text { minutes in Poltava, } \\
\text { up to } 20 \text { minutes in regions) }\end{array}$ & $18(90)$ & $208(25,7)$ & $\begin{array}{c}35,4 \\
(7,993-156,775)\end{array}$ & 0,089 \\
\hline $\begin{array}{l}\text { Start time of PCl after ECG withdrawal } \\
\text { (more than } 120 \text { minutes) }\end{array}$ & 4 & 140 & $\begin{array}{c}0,279 \\
(0,091-0,853)\end{array}$ & 0,014 \\
\hline DS: STEMI & $20(100)$ & $266(89,9)$ & \multirow{2}{*}{$\begin{array}{c}0,930 \\
(0,901-0,906)\end{array}$} & \multirow{2}{*}{0,127} \\
\hline DS: NSTEMI & 0 & $30(10,1)$ & & \\
\hline Diabetes mellitus & $17(85,0)$ & $23(7,8)$ & $\begin{array}{c}67,261 \\
(18,348-46-567)\end{array}$ & 0,001 \\
\hline
\end{tabular}

factors such as aneurysm, arrhythmia, reducing the ejection fraction of the heart, cardiogenic shock, and pulmonary edema were considered. Most of the patients noted improving health - 148 (60,7\%). After conducting of cardio-intervention treatment there is $85(34,8 \%)$ patients with different complications: one complication was 46 (18,9\%), combined complication - 37 (15,2\%), the patient died - 10 (4.1\%) (Fig.1).

The next step in our study was a two-dimensional analysis, which was performed using tables of conjunction and odds ratio. The chance of getting complications after cardiovascular intervention increases 8.0 times in the summer: OR is 8,052 (95\% CI 4,305 - 0,232), p<0,001 (Table II). Significant associations were obtained between the age of the patient and the number of complications. Analyzing the relationship between the risk of complications of cardio-interventional intervention and the gender of the patient, it was found that men had a $35 \%$ lower risk of complications of cardio-interventional manipulations (OR is 0,655 (95\% CI 0,426-0,972), $\mathrm{p}=0,024$.
In people over 70, the chances of getting complications are reduced by $50 \%$ : OR is 0,508 (95\% CI 0,261 - 0,987), $\mathrm{p}=0,050$. Investigating the relationship between the risk of complications and the place of residence (Poltava, districts), no reliable correlation was found. It is revealed that such diagnosis as recurrent myocardial infarction of another specified localization (code according to IHD - 122.8) increases the risk of complication development by 2.1 times: OR is 2,15 (95\% CI $1,224-5,183), p=0,014$. The timely arrival of an emergency care team reduces the chances of complications from cardio-intervention by $55 \%$ : OR is 0,453 (95\% CI 0,255 - 0,806), $\mathrm{p}=0,008$. Established diagnosis - STEMI increases the risk of complications after intervention by 2.2 times: $\mathrm{OR}$ is 2,284 (95\% CI 1,022 - 5,103) $\mathrm{p}=0,027$. According to the calculations, concomitant diabetes mellitus is extremely dangerous in the aspect of complications - it increases the risk after cardio-interventional complications by 84 times: OR is 84,2 $(95 \%$ CI $45,1-157,2) \mathrm{p}=0,001$. The presence of concomitant 
Table 4. Risk factors affecting the early complication of AMI with cardio-intervention and late arrival of ambulance

\begin{tabular}{|c|c|c|c|c|c|c|c|}
\hline STEP №№ & Prognostic factor & Coef. B & $\begin{array}{c}\text { Stand. } \\
\text { deviation }\end{array}$ & Wald. & df & Sig. & $\operatorname{Exp}(\beta)$ \\
\hline \multirow{5}{*}{ Step 1} & Season & & & 10,731 & 3 & 0,013 & \\
\hline & Winter & 0,044 & 0,158 & 0,079 & 1 & 0,779 & 1,045 \\
\hline & Spring & $-0,235$ & 0,175 & 1,798 & 1 & 0,180 & 0,791 \\
\hline & Summer & $-0,517$ & 0,183 & 7,972 & 1 & 0,005 & 0,596 \\
\hline & Autumn & $-0,347$ & 0,151 & 5,311 & 1 & 0,021 & 0,707 \\
\hline \multirow{7}{*}{ Step 2} & Age over 70 years & $-0,106$ & 0,113 & 0,894 & 1 & 0,345 & 0,899 \\
\hline & ECG diagnosis - STEMI & 0,669 & 0,212 & 9,935 & 1 & 0,002 & 1,953 \\
\hline & Diabetes mellitus & 1,449 & 0,296 & 23,983 & 1 & 0,000 & 4,259 \\
\hline & $\begin{array}{c}\text { Anamnesis of atrial } \\
\text { hypertension }\end{array}$ & 0,148 & 0,198 & 0,562 & 1 & 0,453 & 1,160 \\
\hline & Renal pathology & 0,215 & 0,188 & 1,313 & 1 & 0,252 & 1,240 \\
\hline & Smoking & 1,095 & 0,293 & 13,986 & 1 & 0,000 & 2,988 \\
\hline & High BMI & 0,726 & 0,239 & 9,218 & 1 & 0,002 & 2,066 \\
\hline
\end{tabular}

renal pathology increases the risk of complications by 4.9 times: OR is $4,93(95 \% \mathrm{CI} 3,144-7,741) \mathrm{p}=0,001$. Smoking is extremely dangerous for the development of complications smokers have a 19.6-fold increased risk of complications: OR is $19,674(95 \% \mathrm{CI} 10,6-36,4) \mathrm{p}=0,001$. A similar pattern is also observed for patients with a high BMI, which increases the risk of complications by 26.7 times: OR is 26,754 ( $95 \% \mathrm{CI}$ $15,572-45,96), p=0,001$. A significant influence of the type of treatment of AMI (stenting, conservative therapy) on the development of complications has been identified.

In determining of the risk factors that affect the mortality rate of patients with AMI, it was found that the risk of death higher in people older than 70 years in $8 ? 5$ times: $\mathrm{OR}=8,591$ (95\% CI 3,322 - 4,218), $\mathrm{p}=0,001$; in those who have repeated myocardial infarction of another specified localization in 14 times: OR $=14,500(95 \% \mathrm{CI} 4,684-14,890) \mathrm{p}=0,001$; anamnesis of diabetes mellitus increase risk of death in 67 times: OR $=67,261(95 \% \mathrm{CI} 18,348-46-567), p=0,001$. The fact that the start time of PCI after ECG withdrawal (more than 120 minutes) reduces the risk may indicate that not all patients admitted to the hospital do PCI (Tab. III).

Based on the data obtained, one can speak of a diagnostic model of risk factors for early complications of AMI after cardio-intervention treatment. Finding that the timely transportation of a patient with GIM by ambulance forces is a significant factor, we investigated what additional factors would affect the untimely delivery of a patient to a tertiary level of health care system. To determine the factors that influence the early complication of AMI after cardio-intervention treatment, the Cox regression equation included predictors that were significant in determining of OR: season, age over 70 years, male gender, ECG diagnosis - STEMI, presence of diabetes mellitus, anamnesis of atrial hypertension, renal pathology, smoking, high BMI. Using of the regression analysis, we determined the factors that affect the early complication of AMI with cardio-intervention treatment (with timely arrival of the emergency).

According to the data analysis, 276 observations were identified as censored. This is the time of arrival of the ambulance, which was more than 10 minutes in the city of Poltava or more than 20 minutes in the districts.

Table 4 shows the model constructed by the likelihood ratio method. Thus, in the first step of the analysis the model includes the alternating season: winter, spring, summer, autumn; the second stage included: age over 70 years, male gender, ECG diagnosis - STEMI, presence of diabetes mellitus, anamnesis of atrial hypertension, renal pathology, smoking, high BMI.

We found significant relationships for cases of early complication of AMI in cardio-interventional treatment, as evidenced by predicted changes in risk when changing the value of the independent variable by one (Table IV).

In the first step of the study, the most significant variables were "summer" $-\exp (\beta) 0,596(p=0.005)$ and "autumn" - $\exp$ ( $\beta$ ) $0.707(p=0.021)$ - where the relative risk of complication decreased by $41.4 \%$ with each minute those who received a third of the level of care in the summer and $29,3 \%$ in the autumn. Obviously, the risk of complications in the summer and autumn is reduced when arriving by ambulance up to 10 minutes in the city and 20 minutes in the countryside, since the roads are better at this time than other seasons.

In the analysis of the second step of the equation, significant factors were: ECG diagnosis (STEMI), which increased the risk of complications by 1,9 times - exp ( $\beta$ ) $1,953(\mathrm{p}=0,002)$; presence of diabetes mellitus by 4,25 times $-\exp (\beta) 4,259(\mathrm{p}=0.001)$; smoking by 2,98 $(\mathrm{p}=0.001)$ and high BMI by 2 times $(\mathrm{p}=0,002)$.

The estimates of the respective coefficients, as well as the graphs constructed for the mean values of the independent variables, are shown in Fig. 2, 3.

Each point and segment on the survival curve indicated the probability that the patient was in a higher risk zone of getting early complications of AMI with cardio-interventional treatment with each minute of delayed ambulance arrival. After 10 minutes there is a sharp increase in relative risk, which stops for 20 minutes, after which the number of patients who will have complications increases. 

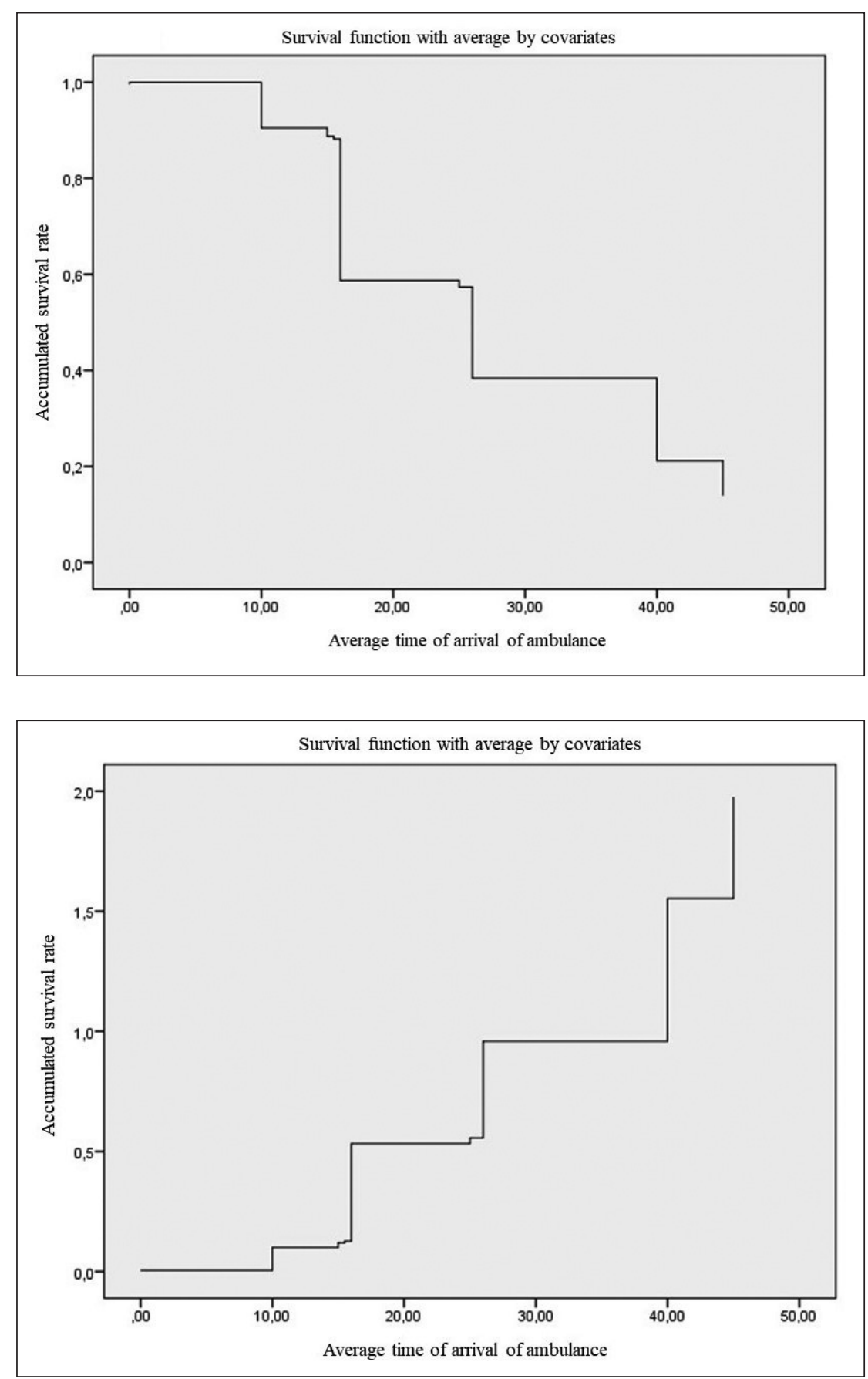

Fig. 2. Dependence of occurrence of early complications of AIM with cardio-interventional treatment for mean values of ambulance arrival covariates

Fig. 3. Risk function of early complications of AIM with cardiointerventional treatment for the mean values of ambulance time of arrival covariates.

\section{CONCLUSIONS}

As a result of the conducted research, the risk factors for early complications of AIM with cardio-interventional treatment were identified. Thus, the factors that increase the chances of their occurrence were: summer time of year: $\mathrm{OR}=8,052$ (95\% CI 4,305 - 0,232), ( $<<0.001)$; recurrent myocardial infarction of another specified localization (ICD code: 122.8): OR = 2,15 (95\% CI 1,224 - 5.183), $\mathrm{p}=0,014$; the relevance of the established STEMI diagnosis: $\mathrm{OR}=2,284(95 \%$ CI 1,022-5,103) $\mathrm{p}=0,027$; diabetes mellitus: OR $=84,2$ (95\% CI 45,1-157,2) p=0,001; renal pathology: $\mathrm{OR}=4,93$ (95\% CI 3,144-7,741) $\mathrm{p}=0,001$; smoking: $\mathrm{OR}=19,674(95 \% \mathrm{CI} 10,6-36,4) \mathrm{p}=0,001$; high rete of BMI: $\mathrm{OR}=26,754$ (95\% CI 15,572-45,96), $\mathrm{p}=0,001$.
Factors that reduce the chances of their occurrence: in men, the risk of complications of cardio-interventional treatment in 35\% lower: OR $=0,655$ (95\% CI 0,426 $0.972) p=0,024$; over the age of 70 , the chances of getting complications are reduced by $50 \%$ : OR $=0,508$ (95\% CI $0,261-0,987), p=0,050$; the timely arrival of an emergency medical team reduces the chances of complications from cardiovascular intervention by $55 \%$ : OR $=0,453(95 \% \mathrm{CI}$ $0,255-0,806), \mathrm{p}=0,008$.

Risk factors have been identified that affect the mortality of patients with AMI. The factors that increase the chances of their occurrence were: age over 70 years - $\mathrm{OR}=8,591$ (95\% CI 3,322-4,218) $\mathrm{p}=0,001$; subsequent myocardial infarction of unspecified site: OR=14,500 (95\% CI 4,684- 
14,890), $\mathrm{p}=0,001$; diabetes mellitus - OR $=67,261(95 \%$ CI 18,348-46-567), $\mathrm{p}=0,001$.

Using of a Cox regression analysis, it was proved that the cumulative risk of early complications of AMI with cardio-intervention treatment increased from the 10th minute of ambulance arrival at place, when ECG diagnosis (STEMI), which increased the risk of complications by 1,9 times $\exp (\beta) 1,953(p=0,002)$; presence of diabetes mellitus by $4,25$ times $-\exp (\beta) 4,259$ ( $\mathrm{p}=0.001)$; smoking by 2,98 $(\mathrm{p}=0.001)$ and high BMI by 2 times $(\mathrm{p}=0,002)$.

\section{REFERENCES}

1. Bechthold A., Boeing H., Schwedhelm C. etal. Food groups and risk of coronary heartdisease, stroke and heartfailure: Asystematicreview and dose-response meta-analysis of prospective studies. Critical Reviews in Food Science and Nutrition. 2019; 59:7, 1071-1090; D0I:10.1080/10408398.2017.1392288

2. Zhdan, V.M., Holovanova I.A., Filatova V.L. et al Medical evaluation of efficiency of optimized models for early detection and primary prevention of cardiovascular diseases. Wiad. Lek. 2017; 70 (1): 433-438.

3. De Bacquer D., De Smedt D., Kotseva K. et al. Incidence of cardiovascular events in patients with stabilized coronary heart disease: the EUROASPIRE IV follow-up study. Eur J Epidemiol. 2019; 34, 247-258; https://doi.org/10.1007/s10654-018-0454-0

4. Case B.C., Waksman R. Coronary Heart Disease: Have We Reached a Plateau in Primary Prevention? Journal of the American Heart Association.2020;9:e04963; https://doi.org/10.1161/JAHA.120.016034

5. Brunetti N.D., Di Pietro G., Aquilino A. et al. Pre-hospital electrocardiogram triage with tele-cardiology support is associated with shorter time-toballoon and higher rates of timely reperfusion even in rural areas: data from the Bari- Barletta/Andria/Trani public emergency medical service 118 registry on primary angioplasty in ST-elevation myocardial infarction. European Heart Journal: Acute Cardiovascular Care. 2014; 3(3), 204-213; https://doi.org/10.1177/2048872614527009

6. Knoery C.R., Heaton J., Polson R. et al. Systematic review of clinical decision support systems for pre-hospital acute coronary syndrome identification. Critical Pathways in Cardiology: 2020 Mar 11. doi: 10.1097/HPC.0000000000000217

7. Pil-Sang Song, Myung Ho Jeong. Incidence, Predictors, and Implications of Re-Hospitalization for Heart Failure after Acute Myocardial Infarction. Journal of Cardiac Failure. August 2019; Volume 25, Issue 8, Supplement, Page S151; https://doi.org/10.1016/j.cardfail.2019.07.435

8. Saleh A., El-Amin A., El-Baz M. et al. Assessment of Myocardial Viability After Acute ST- Elevated Myocardial Infarction Using Stress Speckle Tracking Echocardiography and Cardiac MRI. The Egyptian Journal of Hospital Medicine. 2019; 77(3), 5173-5182: doi: 10.12816/ ejhm.2019.53303

9. Zhdan V.M., Dvornyk V.M., Bielikova I.V. et al. Epidemiology of diseases of the circulatory system among the population of Poltava region. Wiad. Leka. 2019; 12 (I): 2366-2370.

10. Forte E., Punzo B., Gentile Fet al. Normal patterns of left ventricle rest myocardial perfusion assessed by third-generation cardiac computed tomography. Clin Physiol Funct Imaging. 2020: 40: 30-36. doi:10.1111/ cpf.12598

11. Xing Y., Rao N., Miao M. et al. Task-State Heart Rate Variability Parameter- Based Depression Detection Model and Effect of Therapy on the Parameters. IEEE Access. 2019; vol. 7, pp. 105701-105709; https:// ieeexplore.ieee.org/abstract/document/8784161
12. Killip T., Kimball J.T. Treatment of myocardial infarction in a coronary care unit. A two year experience with 250 patients. Am J Cardiol. 1967 0ct; 20(4):457-64.

13. Mostafa M., Attia W., Taha M. et al. Assessment of Left Atrial Function in Patients with Non-ST-Segment Elevation Myocardial Infarction Using Two-Dimensional Speckle Tracking Echocardiography. The Egyptian Journal of Hospital Medicine. 2018; 73(4), 6562-6570; doi: 10.12816/ ejhm.2018.15418

14. Chen Kan, Hui Yang. Internet of Hearts - Large-Scale Stochastic Network Modeling and Analysis of Cardiac Electrical Signals. Stochastic Modeling and Analytics in Healthcare Delivery Systems. 2017.P. 211-251 https:// doi.org/10.1142/9789813220850_0009

15. Khorosh M.V., Harkavenko M.O., Holovanova I.A. Risk factors for development of hypertension in Poltava region. Wiadomosci Lwkarskie. 2016; 2:190-197.

16. Mannheimer C., Camici P., Chester M.R. et al. The problem of chronic refractory angina. Report from the ESC Joint Study Group on the Treatment of Refractory Angina. European Heart Journal. 2002; 23, 355-370 doi:10.1053/euhj.2001.2706

17. Parchomenko 0.M. et al. Rekomendaczi' yi asoczi' aczi' yi kardi' ologi' v Ukrayini shhodo vedennya paczi yenti $v$ z gostrim koronarnim sindromom z elevaczi yeyu segmenta ST. [Recommendations of the Association of Cardiologists of Ukraine on the management of patients with acute coronary syndrome with ST segment elevation].http://www. webcardio.org/Data/Sites/1/lecture/recomendacii-2.pdf

Research work "Medico-social substantiation of optimization of approaches to the management and organization of various types of medical care for adults and children in the period of health care reform" (№ 0119U102926).

\section{ORCID and contributorship:}

Iryna A. Holovanova - 0000-0002-8114-8319 A,F Grygori A. Oksak - 0000-0003-0179-3439 B,F

Iryna M. Tkachenko - 0000-0001-8243-8644 D,E Maxim V. Khorosh - 0000-0002-2083-1333 C,D

Mariia M. Tovstiak - 0000-0002-4837-6061 ${ }^{C, D}$

Yevhen Yu. Strashko - 0000-0002-5165-9978 ${ }^{B}$

\section{Conflict of interest:}

The Authors declare no conflict of interest.

\section{CORRESPONDING AUTHOR Maxim V. Khorosh}

Ukrainian Medical Stomatological Academy

Shevchenko 23 str., 36011 Poltava, Ukraine

tel: +380965387040

e-mail.: indarion0@gmail.com

Received: 27.02.2020

Accepted: 30.04 .2020 